\title{
THE SCIENTIFIC ACTIVITIES OF ALEXANDER FLEMING, OTHER THAN THE DISCOVERY OF PENICILLIN
}

\author{
by \\ RONALD HARE*
}

\section{THE BEGINNING}

ALEXANDER FLEMING was born in 1881 on a remote farm in Ayrshire; he was educated at Darvel village school four miles away over rough moorland, and at Kilmarnock Academy. When he was thirteen and a half, he went to live in London, where he became a clerk in a shipping office. Four years later, his inheritance of $£ 250$ enabled him to start training for a medical career. He entered St Mary's Medical School with a scholarship in Natural Sciences, which exempted him from the payment of fees. He passed the qualifying examination of the Conjoint Board in 1906 when he was twenty-five years old. Without private means, he started to work in the Pathology Department, for which he was paid a small salary. He finished his medical education in 1908 by taking the London MB BS (gold medal), and soon afterwards passed the final examination for the Fellowship of the Royal College of Surgeons. He then became a member of the team at St Mary's Hospital (Figure 1) led by Sir Almroth Edward Wright; they were to work together for the rest of their lives. ${ }^{1}$

Wright had come to St Mary's in 1902 from the Army Medical School at Netley, overlooking Southampton Water, where he had produced a vaccine for the prevention of typhoid fever. Shortly after his arrival, he had been knighted, elected a Fellow of the Royal Society, and given the Chair of Experimental Pathology in the University of London. He was forty-seven years old, with an already established reputation as a scientist and original thinker, when Fleming joined his team.

With Captain S. R. Douglas, who had been invalided from the Indian Medical Service some time previously, Wright had begun at Netley a study of vaccine therapy, that is, the treatment, as opposed to the prevention, of bacterial infections by injection of killed bacteria, and had already published two papers on the subject. ${ }^{2}$ To ensure correct dosage of the vaccines, they had devised a test called the opsonic index, which was intended to measure the level in the blood of antibody to the infecting organisms. This was considered necessary because by giving too large a dose of vaccine one could

\footnotetext{
* Ronald Hare, MD, The Red House, Guisborough, Northants NN6 8PU.

'L. J. Ludovici, Fleming, discoverer of penicillin, London, Andrew Dakers, 1952. André Maurois, The life of Sir Alexander Fleming, translated by Gerard Hopkins, London, Jonathan Cape, 1959.

${ }^{2}$ A. E. Wright, 'Notes on the treatment of furunculosis, sycosis, and acne by the inoculation of a staphylococcus vaccine and generally on the treatment of localized bacterial infections by therapeutic inoculations of the corresponding bacterial vaccines', Lancet, 1902, i: 874-884. A. E. Wright and S. R. Douglas, 'An experimental investigation of the role of the blood fluids in connection with phagocytosis', Proc. $R$. Soc. Lond., Series B, 1903, 73: 128.
} 


\section{Ronald Hare}

lower the antibody level in what was called a "negative phase" to such an extent that the patient might become worse because he did not have a sufficient margin of resistance to safeguard him against any generalization of the infection. Unfortunately, determination of the opsonic index required a technique that no one except the few workers at St Mary's knew how to employ.

Young doctors were attracted by Wright's original thinking. They were prepared to work very long hours for very small salaries, augmented, where possible, by private practice. Most of them got no more than $£ 100$ a year, paid by Wright himself, who had a large private practice of his own. Fleming and his colleagues carried out no less than 16,000 opsonic tests in one year, each of which required half an hour. ${ }^{3}$ Both the treatment itself and the laboratory tests were so new that visitors from all over the globe were attracted to St Mary's to learn more about them. Some even stayed to join the course of instruction in the opsonic index determination, for which a fee was charged. One such course had no fewer than fifty pupils. The techniques employed, which bear no resemblance to anything before or since, were described in minute detail in a monograph. ${ }^{4}$ Like most of Wright's theories, however brilliantly expounded, the connexion between the opsonic index, dose of vaccine administered, and the cure of the disease was never provided. Consequently, after several years, it was found that the expensive and elaborate procedures required for the determination of the opsonic indices were not really necessary.

Nevertheless, in 1908, vaccines were still in demand for many forms of infection, and what was considered to be the correct dosage could be stated on the label so that practitioners anywhere could administer them. Wright and Douglas seized the opportunity to start production of vaccines in bulk for sale to doctors. A new institution called the Inoculation Department was set up with $£ 17,000$ capital, subscribed by rich patients. It was completely independent of both Hospital and Medical School, and rented suitable accommodation in four wards of the Clarence Wing, which the Hospital itself could not commission for want of money. This provided space for the commercial activities and laboratories for the research workers. The vaccines were marketed by a pharmaceutical firm, Parke Davis \& Co. Ltd.

Douglas took charge of all this, while Wright gave up his private practice, which had been bringing in no less than $£ 6,000$ a year compared to a salary of only $£ 2,000{ }^{5}$ Although the official reason was that he wanted to do research and write, it is more than probable that the real reason was that vaccine therapy had not been the success he had hoped for. The undoubted cures were few and far between, and he had become tired of explaining matters to indignant patients. He accordingly summarized his doctrine and success in a massive volume entitled Studies in immunization. ${ }^{6}$ Fleming had played no part in the evolution of Wright's doctrines or the techniques required, for which reason he can be exonerated from blame for their deficiencies.

\footnotetext{
${ }^{3}$ Sir Zachary Cope, Almroth Wright. Founder of modern vaccine therapy, London, Nelson, 1966, pp. 42-50, 102.

4A. E. Wright, Handbook of the technique of the teat and capillary glass tube, and its application to medicine and bacteriology, London, Constable, 1912.

'L. Colebrook, Almroth Wright, provocative doctor and thinker, London, Heinemann, 1954, p. 105.

-A. E. Wright, Studies on immunization and their application to the diagnosis and treatment of bacterial infections, London, Constable, 1909.
} 


\section{Other scientific activities of Alexander Fleming}

Meanwhile, however, methods other than the opsonic index had been produced for the detection of antibodies in the blood during infections. One of them was complement fixation, employed by August P. von Wassermann and his co-workers in 1905-6 for the diagnosis of syphilis. In 1909, Fleming was allowed to study it in depth, and was able to demonstrate the talent, which never left him, of devising original apparatus and procedures. He published two important papers on the subject in that year. ${ }^{7}$

In April 1910, Paul Ehrlich announced at a congress in Wiesbaden that he had discovered an organic arsenical compound called Salvarsan that could cure syphilis. Since he was having difficulty in obtaining well-controlled trials, he sent samples to Wright, who handed them over to Fleming for this purpose. With the assistance of Leonard Colebrook, another pupil of Wright, Fleming soon improvised a much better method for their administration than that of the Germans, controlled the results with Wassermann tests, and published a paper reporting the value of the new drug. ${ }^{8}$ Soon afterwards, Fleming was appointed pathologist to the London Lock Hospital, and rented a consulting room for the treatment of private patients in a house in Devonshire Place owned by John Freeman, also a disciple of Wright.

Fleming had also interested himself in the part played by the so-called acne bacillus (Corynebacterium acnes) in furunculosis and acne, which had been controversial for some time. He was able to show that it was present in many phases of the disease, so that a vaccine might be helpful in its treatment (see also pp. 361-362). ${ }^{9}$ Nevertheless, there were many who doubted the validity of his findings.

Thus, within three years of becoming a member of Wright's team, Fleming had laid the foundations for a specialist practice in London.

\section{THE FIRST WORLD WAR}

When Britain entered the war on 4 August 1914, vaccines were required for protection against typhoid, paratyphoid, and cholera, and Douglas started production promptly. They were bought by the British armed forces and the governments of Belgium, France, and Russia. The total quantity produced by October 1914 had been as much as 10 million cubic centimetres or 2,000 gallons. The sum paid for this was, of course, never divulged, but in 1914 a bottle containing $25 \mathrm{~cm}^{3}$ of acne vaccine cost $£ 1$ $5 s$. retail, so that the total receipts could have been as much as $£ 500,000$. Neither was this the end, because production continued, and in 1919, Colebrook, then in charge, recorded that he was making $£ 500$ a month after all expenses had been deducted. ${ }^{10}$

. Meanwhile, the army called for help from its former Professor of Pathology, because surgeons were faced with wounds of a type they had never seen before, due

\footnotetext{
${ }^{7}$ A. Fleming, 'A simple method of serum diagnosis of syphilis', Lancet, 1909, i: 1512-1515; idem, 'Serum diagnosis of syphilis by a simple modification of Wassermann's method', Trans Med. Soc. Lond., 1909, 33: 91.

A. Fleming and L. Colebrook, 'On the use of salvarsan in the treatment of syphilis', Lancet, 1911, i: $1631-1634$.

'A. Fleming, 'On the etiology of acne vulgaris and its treatment by vaccines', ibid., 1909, i: 1035-1038.

$10 \mathrm{~W}$. C. Noble, Coli, great healer of men. The biography of Dr Leonard Colebrook FRS, London, Heinemann, 1974, p. 43.
} 


\section{Ronald Hare}

partly to the high explosives employed in modern warfare, and partly to contamination by the heavily manured soil of Flanders and the Somme. Tetanus and gas gangrene were common soon after infliction, and streptococcal infections later. Given the rank of Colonel (but not the appearance or deportment), Wright was installed in what had been a fencing school on the roof of the Casino in Boulogne, and, assisted by younger men from St Mary's, he spent the whole of the war attempting to prevent or cure these infections.

Wright's theories about their causation were delightfully simple. The organisms entered the wound at the time of infliction on the weapon or projectile, or on the skin, clothing, equipment, dirt, and soil forced into it. Once contaminated in this manner, much depended on the ability of the blood, serum, and lymph that flooded the wound to halt the development of the organisms. This, in turn, depended on the species. Staphylococci or streptococci would multiply without much delay, but tetanus or gas gangrene would not. But if the proteins in the exudate were "quenched", as he expressed it, by enzymes released from cells in the tissues, the exudate could support the growth of these latter organisms with an active infection as a result.

The employment of antiseptics to combat this was considered valueless because they were not only inactivated by the proteins but rendered the leucocytes unable to repel the invaders. Instead, Wright advocated the irrigation of the wound with hypertonic saline to promote flooding with fresh unquenched serum that might inhibit growth of some of the invaders, such as those responsible for tetanus and gas gangrene, but would encourage the staphylococci and streptococci to multiply in the fresh serum introduced into the wound. To combat these, Wright's only remedy was the injection of staphylococcal or streptococcal vaccines.

It is extremely doubtful whether these measures had any useful effect on wound sepsis, and it was left to others to be more successful. Tetanus, for example, was overcome within three months of the outbreak of the war by Wright's old enemy Sir David Bruce, who introduced antitetanus serum administered to the wounded as soon as possible. Gas gangrene was to a lesser extent prevented by debridement as used by French surgeons, which cleansed the wound.

In all this, Fleming played little part in the thinking, because captains do not argue with colonels. His function was the devising of the demonstrations that Wright required to get his ideas accepted by the surgeons. Though a superb lecturer, Wright needed experimental support. New modern methods such as lantern slides and cinema films were anathema to him. In their place, the showpieces Fleming produced were exactly what he wanted, and with their aid he was able to ignore all possible alternatives in his reasoning and hypnotize his audience into his way of thinking. This was not the fault of Captain Fleming.

In the end, the captain did better work than the colonel, if only because he took the trouble to find out, as Wright never did, exactly what organisms were infecting the wounds. While still at Boulogne, he had found that the flora was extremely mixed when sampled soon after the infliction of the wound. Many of the organisms present could not even be named, but most tended to disappear leaving only streptococci for the continuation of the infection and eventual death. ${ }^{11}$

${ }^{11}$ A. Fleming, 'On the bacteriology of septic wounds', Lancet, 1915, 11: 638-643. 


\section{Other scientific activities of Alexander Fleming}

Shortly afterwards, Fleming was seconded with another captain from St Mary's, A. B. Porteous, to study the infections and terribly high death rate at a hospital in Wimereux where compound fractures of the femur were being treated. Fleming soon discovered that of the many species of streptococci that might be found in wounds, only those capable of producing a haemolysis were likely to produce severe infections. Using blood agar culture plates on which such organisms produce clear haloes round the colonies, the two investigators examined recently inflicted wounds at a casualty clearing station and found that such streptococci were present in 20 per cent of the wounds at the time of infliction and 20 per cent when they reached the hospital. But a week later, they were found in no less than 90 per cent, with a death rate approaching 50 per cent $^{12}$ (Figure 3 ).

This destroyed Wright's assumption that all the organisms responsible for wound infection were introduced at the time of infliction. It also showed that many of the infections at Wimereux must have been due to what we now call hospital infection: transfer from an infected to an uninfected patient.

A third finding was that the only method of treatment Wright could think of, application of hypertonic saline to cleanse the wound by flooding with fresh serum, was more likely to do harm than good because the serum was an excellent culture medium for streptococci.

\section{POST-WAR}

When, in the early months of 1919 , the departmental warriors returned from France, they found that their future was almost as much in doubt as it would have been nearer the firing lines. The University Grants Committee had decided that St Mary's Hospital Medical School had no future, with a total budget of only $£ 30,000$ per annum, an annual entry of only nineteen students, and no more than 300 beds for teaching purposes. Its buildings were old and dilapidated, and its staff unable to do any research for sheer want of facilities. The only future the committee could think of was as a postgraduate teaching institution. ${ }^{13}$

It was at this point that one of the most remarkable men who ever took up medicine was given control of affairs at St Mary's. This was Sir Charles Wilson, who eventually became, and is better known as, Lord Moran (Figure 2). I will therefore use this name in what follows, for he played a more important part in the penicillin story than has been realized. Born in 1882, he had entered St Mary's as a student in 1902, the same year as Fleming, and also qualified in 1908. After serving as a regimental medical officer during the war, he had been appointed assistant physician at St Mary's in 1919, sub-dean in February 1920, and Dean by the end of the year.

Asking for a stay of execution, he mobilized every resource possible to remedy matters. The shortage of beds and therefore of patients was overcome by persuading Paddington Borough Council to allow consultants and students access to the wards in their Paddington Infirmary not far away. Students were also sent to Queen

${ }^{12}$ A. Fleming and A. B. Porteous, 'On streptococcal infections of septic wounds at a base hospital', ibid., 1919, i: 49-51. 64-65.

${ }^{13}$ Sir Zachary Cope, A history of St Mary's Hospital Medical School, London, Heinemann, 1954, pp. 


\section{Ronald Hare}

Charlotte's Maternity Hospital to improve their midwifery. Another complaint voiced by the Committee, the shortage of whole-time teachers or anyone to organize the teaching of clinical subjects, was soon remedied by the appointment of Dr F. S. Langmead and Mr C. A. Pannett as Professors of Medicine and Surgery by the University of London in $1923 .{ }^{13 a}$ They were given assistants and meagre but usable research accommodation.

Having improved the teaching, Moran's next step was to improve the quality of those taught. Until then, almost anyone with a matriculation certificate and enough money to pay the fees could enter as a student and in due course obtain a licence to practise by passing the examinations of the Royal Colleges of Physicians and Surgeons or even those of a London Livery Company, the Society of Apothecaries, whose examiners tended to be more charitable. Moran accordingly laid it down that any potential student was thenceforth required to possess the necessary certificate enabling him to sit for a university degree in medicine. (Even so, he might not be admitted unless Moran approved of him.) This necessitated an extremely courageous step on Moran's part: he decided against admitting any more women students. Those who had infiltrated the student body during the war left as soon as they qualified. The men who replaced them were carefully selected by a process that required not only an ability to pass written examinations but prowess in other activities, particularly ball games rugby football carrying a much higher rating than hockey or snooker.

Having set his house in order, Moran did not hesitate to advertise its merits. Taking advantage of the fact that one of the newspaper barons, Lord Beaverbrook, was a patient, Moran obtained for St Mary's Hospital Medical School a prominent stall in a so-called Efficiency Exhibition at Olympia from 10 to 26 February 1921, organized by the Daily Express. We students were conscripted to man the stall and operate a machine invented by the Professor of Physiology, B. J. Collingwood, to demonstrate the effect of an electric current on the leg muscles of a dead frog, whenever a large enough crowd had assembled. We were also expected to know all about the more static exhibits in glass showcases, where bottles of vaccine produced by the Inoculation Department were on show. ${ }^{14}$ But, since we were two years away from instruction in bacteriology, there can be little doubt that much we told the assembled crowds was erroneous.

Meanwhile, there had been more immediate problems in the Department itself. It seemed for a time that Wright might go elsewhere. Shortly before the outbreak of

\footnotetext{
${ }^{13}{ }^{3 \mathrm{a}}$ Ibid.

${ }^{14}$ The stall is described in detail in St Mary's Hosp. Gaz., February 1921, vol. 27, no. 2, pp. 15-16: “Any man who inspected the Hospital stall at Olympia, and who listened to the explanations so clearly given by seniors and juniors must have been awakened to the wideness of the field of medical science, and have obtained some glimpse of the far-off horizon to which that science is moving. He saw vaccines in the making and vaccines in the finished form ready for injection. Cultures of bacteria were placed before him, accompanied by the idealised representations in colour of the various occupants of the agar.... Two gastroenemii muscles of a frog were offered for his inspection, one in the full vigour of activity, the other a victim of that tired feeling which makes the whole world akin. These two muscles he saw engaged in a tugof-war, the victor's crown being won by the muscle that knew not the meaning of fatigue.... St Mary's Hospital has by this venture done something of real value to impress upon the lay public the overwhelming importance of research. Now, since we must largely depend upon charity, and since this virtue is said to begin at home, it is no lost labour to bring our Medical School home to the people...."
} 


\section{Other scientific activities of Alexander Fleming}

war, he had been appointed Director of the Medical Research Council's bacteriology division, which was to have been started at the old Mount Vernon Hospital on Holly Bush Hill in Hampstead. Probably because the money made during the war had so improved the Inoculation Department's financial position, he changed his mind and elected to say. ${ }^{15}$ The Medical Research Council awarded him a grant of $£ 2,000$ per annum until he was sixty-five, every penny of which he may have needed because he was maintaining three establishments: his wife's, at Bournemouth; a house in Pembroke Square, Kensington, complete with housekeeper; and an even larger house with an enormous garden at Farnham Royal.

Having decided to stay, Wright then set about rewriting the theories of immunity originally put forward by Pasteur. The result was an enormous paper that required no less than three instalments in the Lancet, ${ }^{16}$ in which was put forward the theory that by adding a vaccine to human defibrinated blood, the leucocytes would be stimulated to produce antibodies themselves, which, if the blood was used for transfusion, would go a long way to curing the patient of his infection. Needless to say, these immunotransfusions, as they were called, were a complete failure, but this did not deter Wright from spending the next twenty years attempting to prove his hypothesis.

Denied of Wright, the MRC appointed his deputy, S. R. Douglas, who left the Inoculation Department in 1919, Fleming filling his place as Assistant Director. Since Douglas had been in full charge of the Department's commercial activities, this meant that Fleming not only inherited these projects but would probably succeed Wright when he retired. It was a promotion of very considerable importance.

There had, however, been another contender, John Freeman, one of Wright's earliest disciples who, with Leonard Noon, had become an expert on allergies in general and hay fever in particular. He had not been one of Wright's team in France, but had been recruited by Douglas for the procurement of new strains of cholera vibrio for the manufacture of vaccines. The nearest were apparently in Galicia, for which reason Freeman was promoted Lieutenant-Colonel (he had been a lancecorporal in the South African war), and as adviser on bacteriological matters to the Russian army, was sent to fetch them. He returned by way of Murmansk, where cold weather was a common commodity. Cholera vibrios being particularly sensitive to cold, Freeman succeeded in keeping his alive by passing his water over the tubes every time nature called upon him. After delivering them, still alive, he deserted his Russian army and migrated to France. But the semi-monastic atmosphere in Wright's headquarters in Boulogne was not to his taste; he transferred to the fleshpots of Paris, where he joined Georges Dreyer, the Professor of Pathology at Oxford, who was busy with the production of oxygen equipment for high-altitude flying. Here he spent the rest of the war.

In almost every respect, Freeman was the exact opposite of Fleming. Born of rich parents, educated at Charterhouse and Oxford, where he took Greats, he was tall handsome, with excellent manners, an ebullient conversationalist, and much given to the society of women with very blue stockings. He was the one man in Wright's

1s Colebrook, op. cit., note 5 above, p. 105.

${ }^{16}$ L. Colebrook, E. J. Storer, and A. E. Wright, 'New principles in therapeutic inoculation', Lancet, 1923, i: $365-373,417-420,473-478$. 


\section{Ronald Hare}

entourage who could talk back at him. It was probably because of this that Wright had promised Freeman the eventual succession. Unfortunately, Freeman had never forgotten this, so that he was bitterly disappointed when Fleming was appointed Assistant Director, thus making him a strong favourite for the future directorship. Consequently, Wright learned to be extremely careful about giving favours and granting assistance or unusual facilities.

\section{PRODUCTION MANAGER}

It was against this background that Fleming started what was to become his real career for the next thirty-four years. Because of the misconception by every subsequent commentator about Fleming's normal activities, we must discuss in some detail precisely what the appointment really meant. It entailed taking complete charge of the commercial activities of the Department to produce enough money to finance the research workers. The sum required for this was considerable, for it provided laboratory space and facilities for seventeen medical men. Some were lodgers with grants from the MRC or other bodies. Some supported themselves with their own money or fees earned elsewhere, but there were seven whole-time workers in the Department as well as Wright and Fleming, and, although no one had a personal technician or secretary, there were at least fifteen technicians, all receiving a living wage that must have been ample because most of them stayed until they retired. Possibly the most important of all was Mr Victor Craxton, the Secretary, a most loyal and devoted soul who has never been given the credit that was his due.

Salaries were not the only requirements. The Department helped the Hospital by paying rent for the four wards it occupied; by providing, free of charge, all the routine bacteriological tests required for the Hospital; and by maintaining ten beds for research purposes. The Medical School also benefited, the Department staff acting as unpaid demonstrators or lecturers, as well as technicians to service the practical classes. But it also financed worthwhile projects in other departments of the Medical School, and paid an annual salary of $£ 200$ for at least one Research Scholar in one of these departments or in the Inoculation Department itself. The annual expenditure was never revealed, but when supplies, materials, and services are considered, it must have been substantial.

In addition to the commercial activities, Fleming was also responsible for much of the research. There was no doubt that certain diseases could be prevented by vaccines, provided they had been administered before the individual came into contact with the organisms concerned. By 1928, these diseases included smallpox, typhoid and paratyphoid, and cholera, while the earlier discovery (1923) by Gaston Léon Ramon that a toxoid could be prepared and quantified by a flocculation test for the prevention of diphtheria and tetanus stimulated Fleming to appoint Dr Lewis Holt to the staff; Holt produced excellent preparations with an aluminium phosphate adjuvant during the 1930s.

On the other hand, vaccines had been found by this time to be of no value at all for the treatment of diseases when the organisms were already established in the tissues and causing symptoms such as pneumonia, meningitis, and all forms of tuberculosis. There was more scope for their employment when the infection became chronic or 


\section{Other scientific activities of Alexander Fleming}

there were periods of remission, as with boils, eczema, and other forms of skin disease, but there was still considerable doubt about the value of vaccines in these cases or for the prevention of colds and influenza, which were beginning to be suspected of being caused by viruses. But there was a possibility that the infections of the chest, middle ear, and mastoid, that might follow the viral infections were due to microbes from which vaccines could be made; administered in the autumn these might confer protection during the following winter. St Mary's did a brisk trade with such vaccines in public schools, the bills for which accompanied the terminal reports on breakfast tables during the holidays and increased fathers' irritation.

Suspensions of killed staphylococci, employed for the prevention of recurrent boils, carbuncles, and furunculosi, were not altogether satisfactory, but the discovery that staphylococci could produce a toxin ${ }^{17}$ and that it could be converted into a harmless toxoid ${ }^{18}$ suggested that a more satisfactory vaccine might be produced. ${ }^{19} \mathrm{~A}$ vaccine that had no connexion with micro-organisms was also marketed for the prevention of hay fever. The pollen grains of the grass Phleum pratense, to which sufferers were sensitive, were collected in a specially adapted farm building in Surrey, then taken to the Department and frozen by liquid air. The resultant deep yellow solution was standardized by Freeman, and the dilutions handled in the same way as the bacterial vaccines. ${ }^{20}$

A number of other vaccines, such as those from bacteria isolated from the so-called septic foci thought to be responsible for arthritis and muscular rheumatism and others in whose production penicillin played a part, are referred to in more detail in a later section (see p. 362).

A third activity of the Department was the confirmation required by the British government of the assays of the tetanus and diphtheria antitoxins made in Detroit by Parke Davis. These tests were carried out by A. F. Hayden, but the ultimate responsibility for the packaging and labelling was Fleming's.

Perhaps the most remarkable aspect of Fleming's commercial activities was the little he had to say about them in the course of conversation and the extreme efficiency with which they were all conducted. A great deal of Fleming's time must have been occupied by the clerical work involved as well as by the actual production of the vaccines, for he was certainly responsible for isolating the organisms used and calculating the dosage of each component. Of his relationship with the pharmaceutical firm that marketed them we heard nothing, and, in fact, it was only on the rare occasions when Mr Maben or Dr White were brought to tea that we realized that there was a factory next door to our laboratory. The technician in charge was W. Clayden, who had been with them in Boulogne as a sergeant in the RAMC. He ran the show, mostly staffed by boys straight from school, with strict discipline. The quarters allotted to them were small, but invariably left spotlessly clean each evening.

${ }^{17}$ F. M. Burnet, 'Production of staphylococcal toxin', J. Path Bact., 1930, 33: 1-16.

18 C. E. Dolman, 'Treatment of localized staphylococcic infections with staphylococcus toxoid', J. Am. Med. Ass., 1933, 100: 1007-1010.

19 A. Fleming and I. H. Maclean, 'On the use of staphylococcus antitoxin, toxoid and vaccine', Abstr. 2nd Internat. Congr. Microbiol., London, 1936, p. 301.

$20 \mathrm{~J}$. Freeman, Hay-fever. A key to allergic disorders, London, Heinemann Medical Books, 1950. 


\section{Ronald Hare}

\section{PROFESSOR OF BACTERIOLOGY}

In 1926, Wright reached the age of sixty-five and had to retire from the Chair of Experimental Pathology he had held since 1902. Moran seized the opportunity to complete his clinical team by engineering the appointment of Fleming as Professor of Bacteriology from 1 October 1928. Fearing repercussions from Freeman, who considered himself equally eligible for the post, Fleming kept the news to himself, and all public pronouncements were banned. There was, in consequence, no celebration, no inaugural lecture, and it was many years before anyone called him Professor.

Having been in charge of the teaching since the war, his new appointment added nothing to his duties. Nor did it alter his style of life. He still had no separate budget, no lecturer to help him or technician he could call his own. He still had to share a very small room, in which there was not even space for a desk. But he obtained something much more important, security of tenure in a laboratory whose chief, Wright, was capable of sacking quite senior members of his staff during fits of temper (and continued to do so until he had reached the age of eighty-four). But professors cannot be dispensed with so rapidly and expeditiously without extensive investigations by the university concerned. Perhaps this was why, only six months after becoming a professor, Fleming could do what no one else in the Department would have dared to do, flatly refuse to delete, on Wright's command, a paragraph in the paper reporting the discovery of penicillin that suggested it might have clinical value.

If Moran was instrumental in providing Fleming with permanent employment until he was sixty-five, he was also responsible for providing him with suitable accommodation. This was one of the consequences of Moran's desire during the mid-1920s to rebuild his medical school, which was then in a serious state of neglect and disrepair. ${ }^{21}$ Collecting sufficient money from Lord Beaverbrook and Lord Revelstoke, Moran planned to erect an entirely new building on two sides of a triangular site adjacent to the hospital. The third, facing Praed Street, was offered to the Inoculation Department, whose premises were also obsolete and inadequate. No one, for example, had an office; the library was beginning to bulge; the only darkroom was a converted fourfoot square w.c.; and the hot-room was in perpetual danger of blowing up because of gas leaks. Even the animals had to suffer, for they had a private residence above a warehouse on the bank of the Grand Union Canal about 200 yards away, and the only place where operations or post-mortems could be carried out was the desk in the lecture room in the main building.

Strange as it may seem, money for the rebuilding was no problem. By contributing $£ 43,000$ from its own funds, plus $£ 40,000$ given by the Chairman of its Council (Lord Iveagh), and the remainder from other well-wishers, the Inoculation Department was able to foot the total bill for $£ 105,000.22$ Precisely when the planning and construction started is not very clear but it must have been about the time Fleming discovered penicillin, and the driving of piles for the foundations certainly made life uncomfortable during 1930. The foundation stone was officially laid in June 1931, and both buildings were declared open in December 1933. There were a few problems with the Department's building. These included the windows, designed and placed in the

${ }^{21}$ R. Hare, The birth of penicillin, London, Allen \& Unwin, 1970.

${ }^{22}$ Cope, op. cit., note 13 above, pp. 66-67, 107; Colebrook, op. cit., note 5 above, pp. 178-179. 


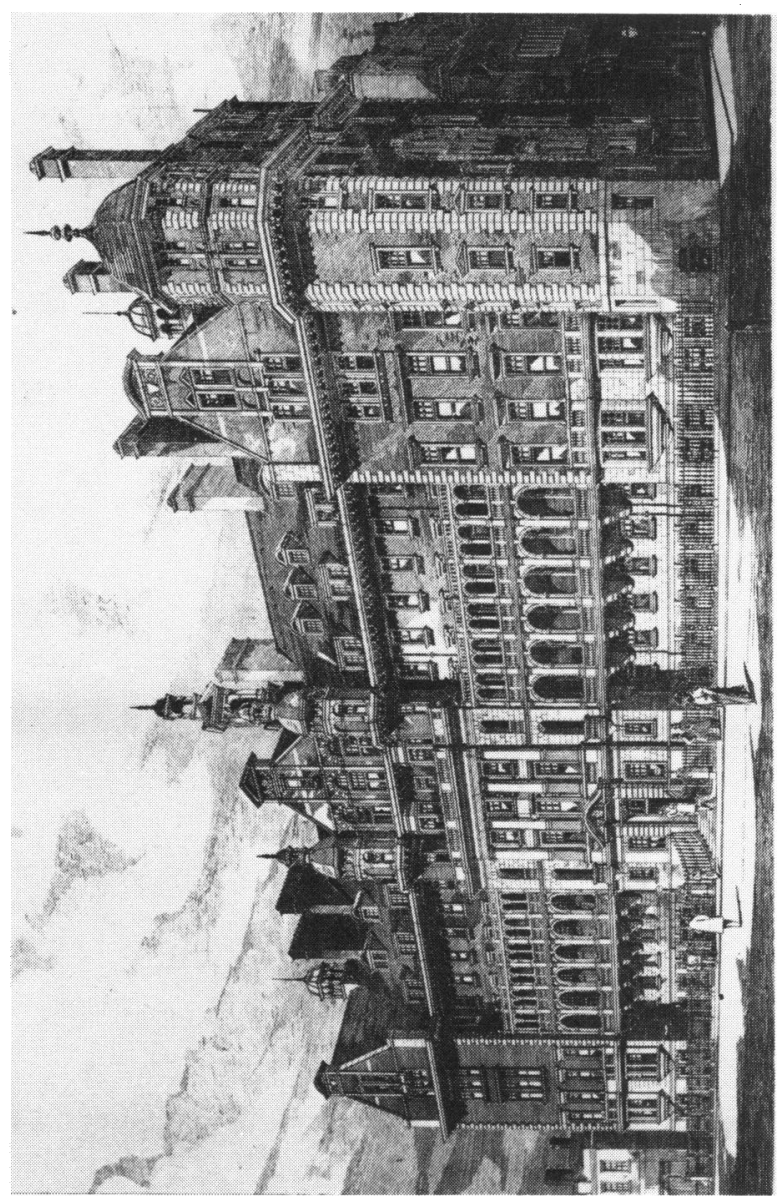

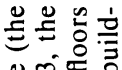

究

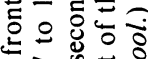

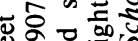

可包的

का $\varepsilon$ क

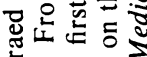

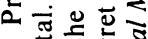

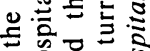

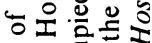

舟

칭영

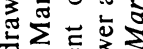

的压呈的

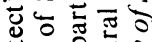

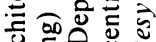

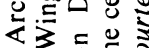

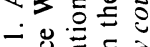

놇 ज्ञ

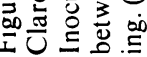

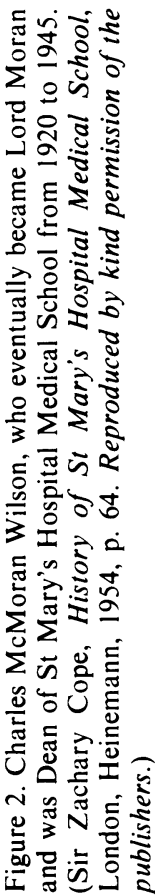

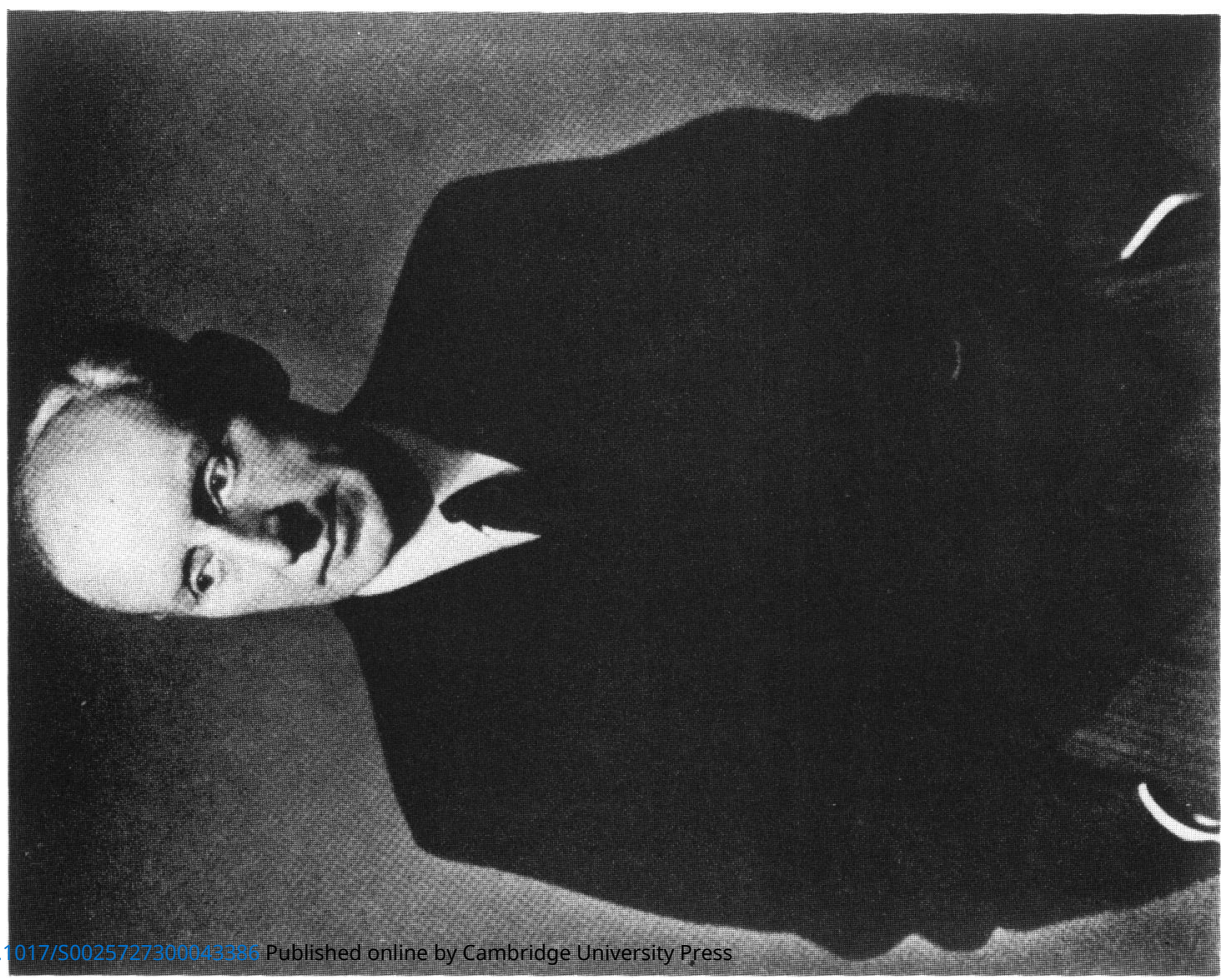




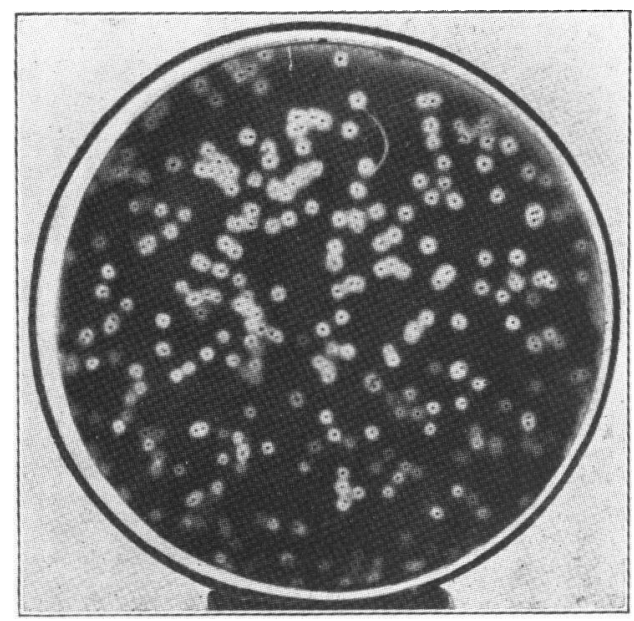

Figure 3. Proof of the importance of haemolytic streptococci in the infection of wounds. This number was present in only $1 \mathrm{~cm}^{3}$ of the circulating blood of a patient with an infected fracture of the femur. (Fleming and Porteous, op. cit., footnote 12, p. 50.)

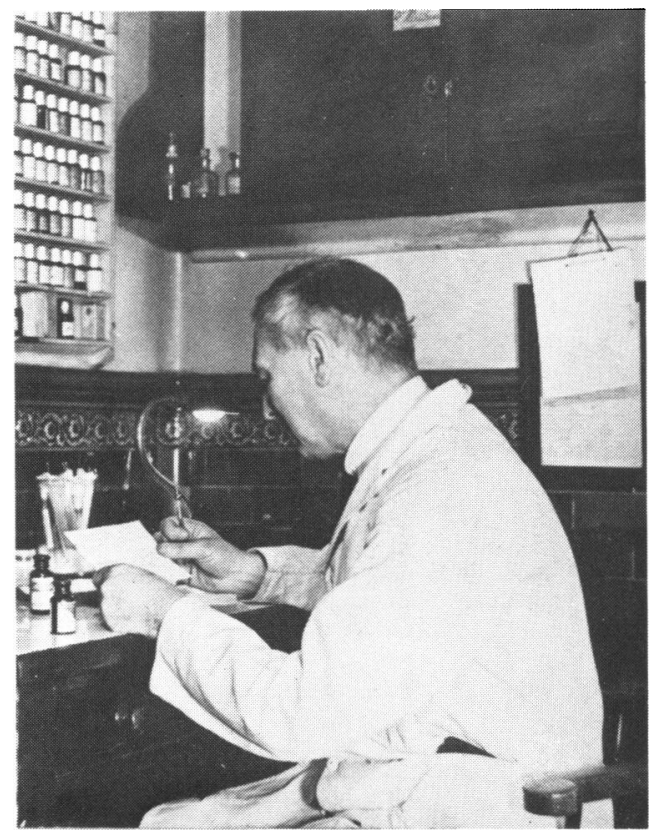

Figure 4. John Freeman, surrounded by the bottles of vaccines used for the treatment of the patients in his enormous clinics.

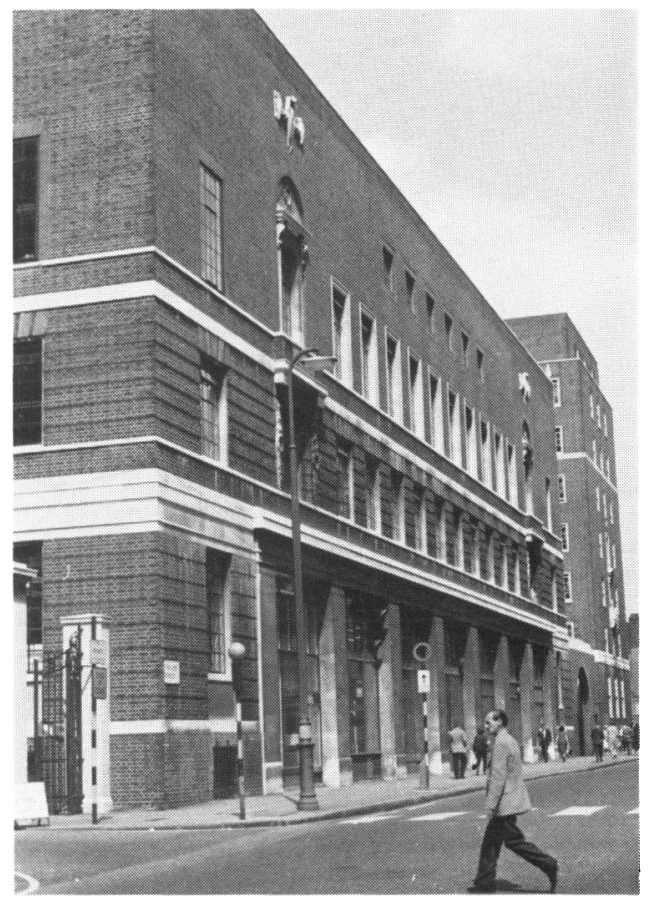

Figure 5. The Wright-Fleming Institute.

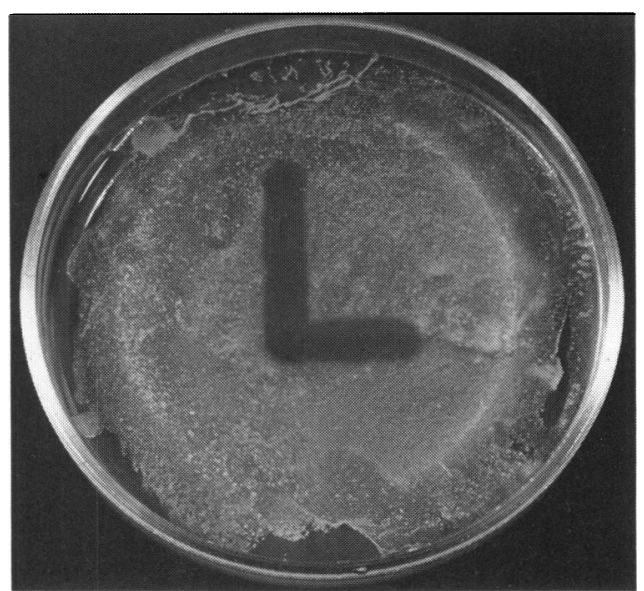

Figure 6. Lysis of susceptible organisms by lysozyme in tears a few seconds after application. 


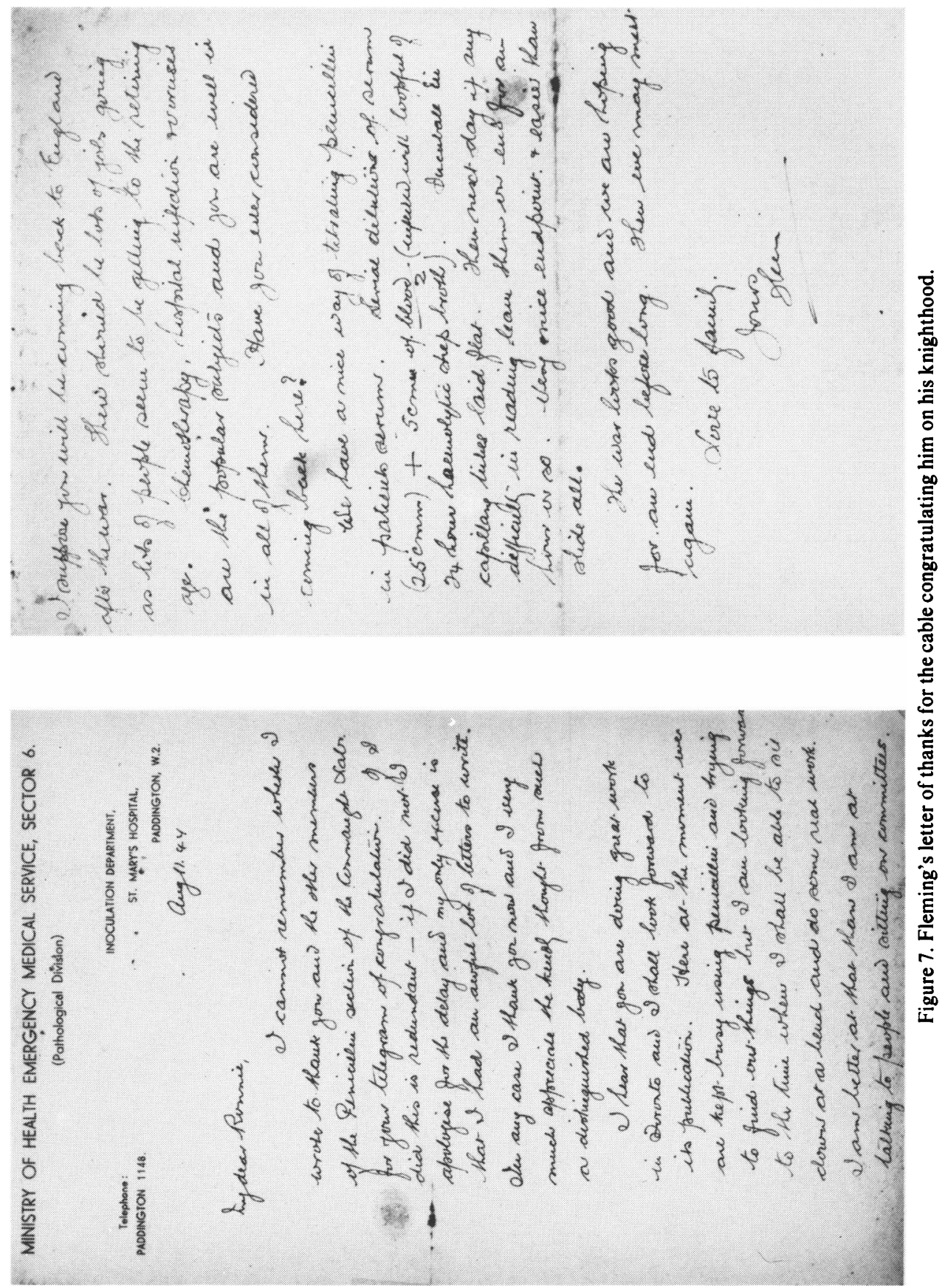




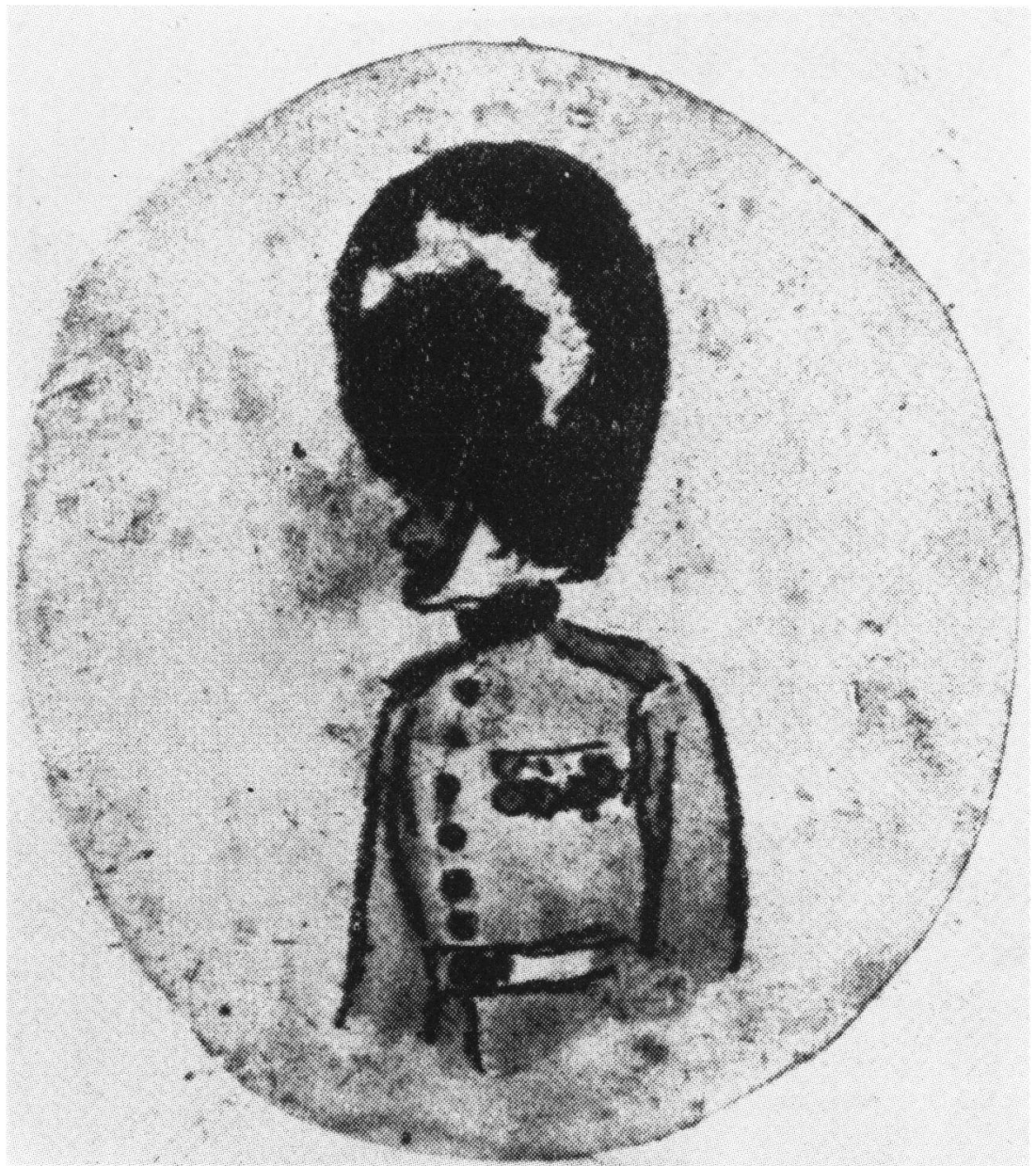

Figure 8. An example of Fleming's employment of microbes for the painting of pictures. (St Mary's Hospital Gazette, 1955, p. 66.) 


\section{Other scientific activities of Alexander Fleming}

appropriate places by the very distinguished architect. He evidently had odd ideas about windows for, on the ground floor facing Praed Street, he insisted on placing a row of large shop windows (with shops behind them). Having failed as shops, they were converted into laboratories, whose inhabitants could obtain daylight but were denied the pleasure of seeing Praed Street because the plate glass was replaced by frosted glass, which also denied passers-by the pleasure of watching science at work. But on the fourth floor the architect denied the inhabitants daylight as well as the view by fitting no windows at all. This was soon remedied when his back was turned by the employment of a pickaxe in suitable places.

In addition to these major problems, there were the smaller ones such as the type of tap that would satisfy both chemists and pathologists, how the seating in the lecture theatre should be planned, and how to prevent Freeman from taking over the whole building for his enormous clinics (Figure 4). Fleming's own needs were comparatively modest, for, although he acquired a larger laboratory, he still had to share it with someone else, but by way of compensation he had, for the first time in his laboratory life, room for a desk. Since acquiring sufficient room and illumination in a new building for a desk requires time and patience, Fleming's work during this period must have been completely disrupted, and it is just possible that the lack of progress that followed the discovery of penicillin may have been due to the simple fact that he was acting more as a clerk of the works than as a learned professor (Figure 5).

\section{FLEMING'S RESEARCHES}

Obviously, a man who was making enough money to finance quite a large research organization was unlikely to find much time for research that had no commercial connexions, but he did so when the opportunity arose. It covered several fields.

\section{Lysozyme}

In a paper published in the Proceedings of the Royal Society in 1922, Fleming reported the discovery of a hitherto unsuspected antibacterial substance that he called lysozyme (Figure 6). It was first noticed during some investigations on a patient suffering from acute coryza. The nasal secretion was cultivated daily on blood agar plates and for the first three days of the infection there was no growth, with the exception of an occasional staphylococcus colony. The culture made on the fourth day showed a large number of small colonies which, on examination, proved to be of large grampositive cocci arranged irregularly but with a tendency to diplococcal and tetrad formation. The microbe has not been exactly identified, but for the purposes of this communication it may be alluded to as Micrococcus lysodeikticus. "The fully developed colony of the coccus may be 2 or $3 \mathrm{~mm}$. in diameter; it is round, opaque, raised, and has a bright lemon yellow colour; it grows luxuriantly on all the ordinary culture media; and good growth occurs at room temperature or in the incubator at $37^{\circ} \mathrm{C}$; it is aerobic and facultatively anaerobic; it does not liquefy gelatin or coagulated albumin."23

Although this was a good description of the microbe whose susceptibility to

${ }^{23}$ A. Fleming, 'On a remarkable bacteriolytic substance found in tissues and secretions', Proc. R. Soc. Lond., Series B, 1921-22, 98: 306-317. 


\section{Ronald Hare}

lysozyme had led to the discovery of the latter, it omits all mention of the unusual appearance of the culture plate that must have been responsible. Whether or not this omission was deliberate will probably never be known, but it was not repaired until after Fleming's death, when it was described by Maurois from information provided by $\operatorname{Dr}$ V. D. Allison, who had been present at the time. ${ }^{24}$ It would appear that the microbe had contaminated the culture plate during the examination soon after the investigation started; that those organisms farthest from the mucus had developed normally; that those nearer the mucus were represented by transparent and glossy circles, and that there had been no colonies at all in the immediate vicinity of the mucus. The obvious conclusion was that the mucus had contained a substance that could diffuse through the agar to prevent development of colonies altogether or halt it in its early stages.

In the subsequent researches, Fleming was assisted by Allison, who had obtained a Beit Memorial Fellowship in 1919 and left the Inoculation Department in 1925 to take up a post as lecturer in the Belfast Medical School. They published no less than seven papers. ${ }^{25}$ Fleming chose lysozyme as the subject for the Arris and Gale Lecture to the Royal College of Surgeons in 1929 and his Presidential Address to the Section of Pathology at the Royal Society of Medicine in 1932, which admirably describes these researches. ${ }^{26}$ There is no doubt that Allison helped Fleming a great deal on what was an entirely new defence mechanism of members of the animal kingdom. Its main function was to protect against many species of organism present in the environment that were not pathogenic but might without such protection have been so. It was found that seventy-four out of a total of 104 strains isolated from the atmosphere were susceptible to its action. Known mammalian pathogens were, however, totally resistant to it.

It was soon found that the new substance was an enzyme acting on organisms in a very different fashion from the standard immunity reactions such as lysis by antibodies in the Pfeiffer phenomenon, or by phagocytosis and intracellular digestion, but which was so powerful that it could produce complete dissolution of susceptible organisms in less than a minute under suitable conditions. Following these preliminary findings, there was a detailed investigation into the sites of the body where lysozyme was produced, and of the fluids that contained it. Its distribution in nature was also investigated.

\section{Chemotherapy}

During his war service in France, Fleming had realized that the treatment of infectious wounds by antiseptics was useless. Although he and Wright had preached

\footnotetext{
${ }^{24}$ Maurois, op. cit., note 1 above, pp. 109-111.

${ }^{25}$ Fleming (1921-22), op. cit., note 23 above; idem, 'A bacteriolytic ferment found normally in tissues and secretions', Lancet, 1929, i: 217; idem, 'Lysozyme', President's Address, Proc. R. Soc. Med., 1932, 26: 78-84; A. Fleming and V. D. Allison, 'Observations on a bacteriolytic substance (lysozyme) found in secretions and tissues', Br. J. exper. Path., 1922-23, 3: 252-260; idem, 'Further observations on a bacteriolytic element found in tissues and secretions', Proc. $R$. Soc. Lond., Series B, 1922-23, 94: 142-151. idem, 'On the antibacterial power of egg-white', Lancet, 1924, i: 1303-1306. idem, 'Development of strains of bacteria resistant to lysozyme action and relation of lysozyme action to intracellular digestion', $B r$. $J$. exper. Path., 1927, 8, 214-218.

${ }^{26}$ Fleming (1932), op. cit., note 25 above.
} 


\section{Other scientific activities of Alexander Fleming}

this doctrine, the experimental evidence was unsatisfactory. It did not rest on experiments with animals infected by human pathogens such as haemolytic streptococci, largely because infected wounds are virtually impossible to produce experimentally. Although generalized infections can be produced, there were departmental objections to the assessment of potentially useful substances by this method in that they were too severe and too rapidly fatal to mimic those in human beings, while the organisms employed to produce them were not those that normally caused animal infections. In their place, both men advocated in vitro methods, assuming that any compound that did not diminish the antibacterial activities of the leucocytes and which could increase the bactericidal power of human defibrinated blood for human pathogens was worth further consideration as a possibly successful therapeutic substance.

For this purpose, a consortium of talent in the laboratory, consisting of Fleming, Wright, Colebrook, Storer, and Dyson, had evolved a piece of apparatus called a slide cell, which was both easy to make and simple in operation. It was made from two microscope slides separated by five strips of vaselined paper arranged at intervals transversely to the long axis of the slides. The space between the slides was thus divided into four compartments open at each end, which would contain about $50 \mathrm{~mm}^{3}$ of blood. After all four compartments had been filled with a mixture of defibrinated blood, the solution under test, and a suitable dilution of organism, usually staphylococcus, the edges were sealed and the apparatus incubated at $37^{\circ} \mathrm{C}$ overnight. Next morning, the number of colonies in each cell were counted. ${ }^{27}$

The technique was employed by Wright, Colebrook, and Storer; by Fry; and by Colebrook and Hare. ${ }^{28}$ But it was used most of all by Fleming, who had found that all the antiseptics employed at that time could, even when present in dilutions too low to kill organisms, be capable of interfering with the ability of the leucocytes to migrate and kill them, thus reducing the bactericidal power of the blood. In this research, he had tested all the current remedies used by surgeons. ${ }^{29}$ Although this technique could detect a substance that was unlikely to be of much therapeutic value, the importance of a potentially useful compound still had to be demonstrated. Nevertheless, this was the method employed for the evaluation of penicillin four years later.

\section{Staphylococcal variants}

During the summer of 1927 , Fleming was asked to write the chapter on the staphylococci for the System of bacteriology that the MRC was about to publish. While doing so, a paper by Bigger, Boland, and O'Meara appeared ${ }^{30}$ describing variant colonies that Fleming thought should be investigated. Dr D. M. Pryce did so, and, after his departure in February 1928, Fleming took up the research himself. Nothing

\footnotetext{
${ }^{27}$ Ronald Hare, 'New light on the history of penicillin', Med. Hist., 1982, 26: 1-24, see pp. 11-13.

${ }^{28}$ Colebrook, Storer, and Wright, op. cit., note 16 above; R. M. Fry, 'The effect of Sanocrysin on $B$. tuberculosis', Br. J. exper. Path., 1926-27, 7: 174-176; L. Colebrook and R. Hare, 'On the bactericidal power of mercurochrome', ibid., 1927, 8: 109-114.

29 A. Fleming, 'A comparison of the activities of antiseptics on bacteria and on leucocytes', Proc. R. Soc. Lond., Series B, 1924, 96: 171-180, see p. 171.

30 J. W. Bigger, O. R. Boland, and R. A. Q. O'Meara, 'Variant colonies of Staphylococcus aureus', J. Path. Bact., 1927, 30: 261-269.
} 


\section{Ronald Hare}

whatever is known about this work, for all the records have disappeared. But it was on one of the plates used for it, Fleming thought, that the phenomenon responsible for the discovery of penicillin had developed.

\section{Penicillin}

The discovery of penicillin has been discussed in considerable detail by the present author in previous communications, in which are given references not only to Fleming's papers but to those of other authors. ${ }^{31}$ Following its discovery, Fleming tested penicillin in slide cells, and found that it behaved in a manner suggesting that it might be of value. About three months later, however, these early hopes were dashed by signs that the new substance might lose a great deal of its activity in the bloodstream, and it was also found that it required more than four hours to kill susceptible organisms. Fleming thought, therefore, that the new substance was unlikely to be useful in treating any form of infection that required its transport to the scene of action by the blood, and it is significant that the attempts by his assistants, Frederick Ridley and Stuart Craddock, to produce a solution suitable for this purpose, which had been much more successful than he ever admitted, were suddenly stopped ${ }^{32}$ It is a striking fact that Fleming never claimed that he had hoped to employ it for the treatment of such diseases as pneumonia or meningitis. He did, however, suggest that it might be of value for the treatment of surface or shallow infections. Except for a cure of a case of pneumococcal conjunctivitis, attempts to treat other surface infections, defined many years later as sinuses and carbuncles, were inconclusive, and for ten more years penicillin as a curative agent was neglected. There were, however, other and more immediately profitable uses for penicillin.

\section{Penicillin in selective media and their commercial value}

Soon after its discovery, it was found that some species of organism were unaffected by penicillin in the highest concentrations available. Among them was an organism first isolated by Richard Pfeiffer during the influenza epidemic of 1889 and suspected by him as the causative agent. It was accordingly called Bacillus influenzae, later Haemophilus influenzae, and referred to by Fleming as Pfeiffer's bacillus. Over the years and several outbreaks of the disease, doubts arose as to its primary role. One of the main problems in investigating the pathogenicity of $H$. influenzae was its production of very slow-growing colonies when cultured on solid media, which were so small and transparent that they could be overgrown by more luxuriant species such as streptococci when specimens from the nose, throat, and sputum of patients were plated out. Since these and other interfering organisms were susceptible to penicillin, Fleming naturally concluded that if penicillin were present in the medium, it would sufficiently inhibit their growth to reveal the colonies of $H$. influenzae.

The technique could not have been simpler. Taking an ordinary culture plate containing a medium suitable for the growth of influenza bacilli such as that described by Fildes, ${ }^{32 a}$ Fleming spread six drops of broth in which the mould had grown on half its

\footnotetext{
${ }^{31}$ Hare, op. cit., notes 21 and 27 above.

32 Hare, op. cit., note 27 above, pp. 14-18.

32a P. Fildes, 'A new medium for the growth of B. influenzae', Br. J. exper. Path., 1920-21, 1: 129.
} 


\section{Other scientific activities of Alexander Fleming}

face, allowed the moisture to be absorbed by the medium, and then inoculated both halves of the plate with the specimens from the respiratory tract and particularly those from the throat. After incubation overnight, the untreated half of the plate had grown the usual large opaque colonies of staphylococci, streptococci, and diphtheroids with few, if any, of the tiny, almost transparent, colonies characteristic of influenza bacilli. These were, however, clearly visible in the absence of competition on the treated half of the plate.

As it happened, there was a visitation of the disease during the spring of 1929 , and Fleming, with the assistance of $\operatorname{Dr} I$. H. Maclean, found that $H$. influenzae was present in the victims, and, equally important, also in a high proportion of others who were unaffected. There was accordingly insufficient evidence to incriminate Pfeiffer's bacillus.

Fleming evidently became so excited about his new technique that he read a paper on the subject to the Medical Research Club on 13 February 1929 at the Middlesex Hospital, less than a month after discovering it. The title of the paper was 'A medium for the Pfeiffer bacillus', but there was no discussion. The new technique was given a prominent place in a paper published in the following June, ${ }^{33}$ and was also the subject of a paper with Maclean in 1930.34

Although it might be suggested that Fleming had merely invented a new laboratory trick to isolate an organism that had little interest for anyone at that time, the results might actually be of considerable commercial value. For if influenza bacilli could be proved to be responsible for the disease, many gallons of vaccine would be required, resulting in an appreciable increase in the departmental budget. In the end, influenza bacilli did not come up to expectations, and only three years later the cause of influenza was shown to be a virus.

The second organism to be studied in this manner was the whooping-cough bacillus, Bordetella pertussis. Here there was no doubt about the connexion between the organism and the disease, and diagnosis was usually possible on clinical grounds alone. But it had recently been shown by Leslie and Gardner ${ }^{35}$ that unless strains of the organism fresh from cases and subjected to as little subcultivation on artificial media as possible were used, they would lose the antigens essential for any protective vaccine. But by eliminating the more prolific streptococci and pneumococci usually present in nasopharyngeal swabs or on cough plates, rapid isolation of the organism in pure culture might be facilitated if penicillin were present. It is, therefore, not surprising that Dr Claude Dolman was despatched to collect suitable specimens from one of the London fever hospitals. ${ }^{36}$

The new technique also enabled Fleming to return to his studies of Corynebacterium acnes, ${ }^{37}$ which had been found in the lesions of acne but never with sufficient frequency to be considered its cause. This was largely due to overgrowth by

\footnotetext{
${ }^{33}$ A. Fleming, 'On antibacterial action of cultures of a Penicillium, with special reference to their use in the isolation of B. influenzae', Br. J. exper. Path., 1929, 10: 226-236.

${ }^{34} \mathrm{~A}$. Fleming and I. H. Maclean, 'On the occurrence of influenza bacilli in the mouths of normal people', ibid., 1930, 11: 127-134.

${ }^{35}$ P. H. Leslie and A. D. Gardner, 'Phases of haemophilus pertussis', J. Hyg., 1931, 31: 423-434.

${ }^{36} \mathrm{C}$. Dolman, personal communication, 1955.

${ }^{37}$ Fleming, op. cit., note 9 above.
} 


\section{Ronald Hare}

staphylococci when specimens from the lesions were cultivated. Even if the organism were present, it was impossible to obtain pure cultures for vaccine production without diminution of the essential antigens required to provide full protection. During the winter of 1929 , Fleming found that $C$. acnes was resistant but not completely so to penicillin, for which reason the comparatively simple technique adequate for the isolation of the influenza and whooping-cough bacilli could not be employed. But by making a series of dilutions of penicillin in broth, each of which was inoculated with specimens from the lesions growth of the acne bacillus - sometimes without staphylococci at all - could generally be obtained. By this method, it was possible to isolate the organism from all the forty-seven cases examined, with the inevitable conclusion that it probably played a part in the causation of the disease. Production of a vaccine without the risk of the organisms losing their essential protective antigens was also achieved. These researches had been carried out by Craddock between May and December 1929, with the paper all ready for publication. But he was tactless enough to be appointed to a post with a rival firm of vaccine producers, Burroughs Wellcome $\&$ Co., to whom he migrated in the New Year. To enable Fleming to capture the market before Burroughs Wellcome could utilize Craddock's expertise, publication of the paper was delayed, and in fact did not appear until $1942,{ }^{38}$ by which time Craddock had become a general practitioner and vaccines had slumped as moneymakers following the arrival of the sulphonamides and penicillin.

As might be imagined, penicillin was of only limited value for the isolation of organisms, so that other substances selectively bacteriostatic were worth consideration. One such was potassium tellurite, whose chief merit was that it could suppress the growth of organisms that were not affected by penicillin, such as those in the alimentary canal, ${ }^{39}$ but allowed it in such organisms as all the streptococci or pneumococci. Some of these organisms were suspected of being responsible for the production of the so-called "septic foci" and the "toxins" causing disease in other parts of the body, such as muscular rheumatism, whose aetiology was at that time very obscure. The septic foci believed responsible were to be found in the alimentary and genitourinary tracts. Because specimens obtained from such sources invariably grew a very mixed flora of organisms, it was difficult to identify the peccant species, and it was probably to overcome this problem that Fleming studied potassium tellurite. However, nothing is known of the clinical or commercial value of these researches.

\section{'Recent advances in vaccine and serum therapy'}

Another of Fleming's activities was the co-authorship with G. F. Petrie of a book, Recent advances in vaccine and serum therapy (1934). ${ }^{40}$ It was divided equally between the two authors, Petrie, who occupied much the same position in the Lister Institute as did Fleming at St Mary's, dealing with serum therapy, while Fleming limited himself to vaccine therapy and prophylaxis.

Following chapters on technical details, Fleming discussed all the vaccines

33 . Craddock, 'Use of penicillin in cultivation of the acne bacillus', Lancet, 1942, i: 558-559.

${ }^{39}$ A. Fleming, 'On specific antibacterial properties of penicillin and potassium tellurite, incorporating [a] method of demonstrating some bacterial antagonisms', J. Path. Bact., 1932, 35: 831-842.

${ }^{\circ} \mathrm{A}$. Fleming and G. F. Petrie, Recent advances in vaccine and serum therapy, London, J. \& A. Churchill, 1934. 


\section{Other scientific activities of Alexander Fleming}

employed at that time except those that required living organisms (such as smallpox and BCG), but including those made from pollen extract and the toxoids employed for the prevention of diphtheria and tetanus. He gave detailed descriptions of each vaccine, whether therapeutic or prophylactic, its composition, the method of preparation, the type of infection dealt with, and the probable results of its employment. He must have spent a great deal of time over this book, for his contribution (about 66,000 words and nearly 400 references to the work of other authors) gives a complete account of the practice of vaccine therapy and prophylaxis only one year preceding the revolution in treatment ushered in by the sulphonamides in 1935. All in all, it is by far the best of Fleming's literary contributions to science.

\section{THE ADVENT OF THE SULPHONAMIDES}

In February 1935, Gerhard Domagk published his paper reporting the discovery of Prontosil, the first of the sulphonamides, ${ }^{41}$ and the fact that it could cure severe haemolytic streptococcal infections was confirmed soon afterwards. ${ }^{42}$ Also in 1935 , it was found that the active principle was sulphanilamide. ${ }^{43}$ This led the way to the discovery of sulphapyridine (M \& B 693) for pneumococcal and sulphathiazole for staphylococcal infections.

Since the prevention of infections by these organisms was the reason behind the manufacture of some of the Inoculation Department's vaccines, its staff may well have started to wonder whether their salaries were quite as safe as they had assumed them to be. To reassure them that all was not lost and that there was still a market for pneumococcal vaccines, Fleming suggested that since sulphapyridine did not actually kill the pneumococci and merely starved them, making them an easy prey for the leucocytes, a dose of pneumococcal vaccine might assist in the curative process. ${ }^{44}$ So far as I am aware, no one seems to have employed this expedient.

Nevertheless, it seems strange that, in view of the threat to the vaccine market from the introduction of the sulphonamides, Fleming was not galvanized into making another attempt to investigate the clinical potentialities of penicillin.

\section{THE CLINICAL ADVENT OF PENICILLIN}

On the outbreak of the Second World War, St Mary's took control of all the hospitals in its Sector, number 6, a triangular area with the hospital itself at the apex and stretching westward as far as Amersham in the north and Basingstoke in the south. Moran was given overall control, with Fleming in charge of the pathological services. His headquarters were at Harefield Hospital, not far from Rickmansworth.

Whether or not the Inoculation Department was called upon to produce large

\footnotetext{
${ }^{41}$ G. Domagk, 'Ein Beitrag zur Chemotherapie der bakteriellen Infektionen', Dt. med. Wschr., 1935, 61: 250-253.

${ }^{42} \mathrm{~L}$. Colebrook and Méave Kenny, 'Treatment of human puerperal infections, and of experimental infections in mice, with prontosil', Lancet, 1936, i: 1279-1286.

${ }^{43} \mathrm{~J}$. Tréfouël et al., 'Activité du p-aminophénylsulfamide sur les infections streptococciques expérimentales de la souris et du lapin', $C$. $R$. Soc. Biol. (Paris). 1935, 120: 756-758.

${ }^{44}$ A. Fleming, I. H. Maclean, and K. B. Rogers, 'M and B 693 and pneumococci', Lancet, 1939, i: 562-568.
} 


\section{Ronald Hare}

quantities of typhoid, paratyphoid, and cholera vaccines, as had been the case during the First World War, has not been revealed. But the Department continued to function, and John Freeman used part of the premises for the blood transfusion services for which he had become responsible. But perhaps the most remarkable aspect of the Department was the tenacity with which its Director, Almroth Wright, clung to his office despite his seventy-eight years, travelling to London on three days a week from Farnham Royal for no particular reason, and doing nothing when he got there. Unfortunately, he eventually found something to do, to which reference will be made below.

On 24 August 1940, the first of the papers by the Oxford workers, under Florey, was published. ${ }^{45}$ It described the production and purification of penicillin with sufficient potency to protect animals experimentally infected by Streptococcus pyogenes, Staphylococcus aureus, and Clostridium septique. So impressive were the results that on 2 September, Fleming went to Oxford to see Florey, Heatley, and Chain (the latter thought he had died long ago). He returned to London that evening, with a small sample of one of the Oxford preparations. He used this for a slide cell experiment to assess its clinical value, and published the results soon afterwards. ${ }^{46}$ They indicated that penicillin behaved in a manner expected of a successful therapeutic substance. But it is significant that no reference was made to a similar experiment that I have already described in this journal, carried out with unpurified penicillin in 1929, which had suggested that it might be inactivated by contact with the fluid elements of blood. ${ }^{47}$

On 16 August 1941, the second of the Oxford papers was published, ${ }^{48}$ giving in considerable detail the results obtained with five patients suffering from infection by Staph. aureus and one by Strep. pyogenes. Despite the long duration of the infections before treatment started and the almost hopeless prognosis, only two died. Probably because the new substance was so difficult to produce, little notice was taken of this paper by medical men and none at all by the public press. It had, however, been noticed by Almroth Wright, and with considerable distaste because he had been preaching the doctrine for many years that chemotherapy for bacterial infections would never be a success and that the only alternative was immunization of some kind. The arguments had been kept more or less muted because neither alternative had been particularly successful until the sulphonamides began to tip the balance - to such an extent that Wright had complained bitterly that his favourite pupil, Colebrook, had "gone a-whoring with them". The exasperated Colebrook retorted, "Why can't I be allowed to go my own way now - after all, I am fifty-five". Further attempts to dissuade Colebrook ended with Wright getting angina, so Colebrook found it safer to

4s E. Chain, H. W. Florey, A. D. Gardner, N. G. Heatley, M. A. Jennings, J. Orr-Ewing, and A. G. Sanders, 'Penicillin as a chemotheropeutic agent', Lancet, 1940, ii: 226-228. Full details of the Oxford researches are given in Gwyn Macfarlane, Howard Florey. The making of a great scientist, Oxford University Press, 1979, pp. 272-346.

${ }^{46}$ A. Fleming, 'In vitro tests of penicillin potency', Lancet, 1942, i: 732-733.

${ }^{47}$ Hare, op. cit., note 27 above, pp. 15-16.

4 E. P. Abraham, E. Chain, C. M. Fletcher, H. W. Florey, A. D. Gardner, N. G. Heatley, and M. A. Jennings, 'Further observations on penicillin', Lancet, 1942, ii: 177-189. 


\section{Other scientific activities of Alexander Fleming}

say nothing - which only made matters worse. ${ }^{49}$

Although Wright's objections may appear to have been ideological in origin, it is possible that there was another reason: that, since Domagk had been awarded the Nobel Prize for the discovery of the sulphonamides, Fleming and the Oxford group might be similarly honoured while he, Wright, would go to his grave Nobel prizeless and be forgotten. It must have been this consideration, for I can think of no other, that had prompted him to remind the Nobel committee that he was still alive by republishing his major works of long ago. Not surprisingly, considering the fact that the war was becoming increasingly desperate, the original publishers refused to cooperate, but another was found who would, provided he was guaranteed against loss. For this purpose, the Departmental Committee were approached and, according to Cope, "were proud to associate themselves with their publication". ${ }^{30}$

The first of these masterpieces appeared in 1942 with a topical title, Pathology and treatment of war wounds. Two more were published in 1943: Researches in clinical physiology and Studies on immunization; with a fourth, Studies on immunization, 2nd series, in 1944. The order in which they appeared certainly suggests that personal advertisement had been the real purpose of the exercise rather than recommendation of immunization. But the project was a failure. According to Cope, "The reception of these volumes was disappointing but this was not altogether surprising for some of the articles had been published many years previously and very little new material was added in the new volumes." ${ }^{51}$ An unnamed reviewer in the Journal of Pathology and Bacteriology was evidently of the same opinion, complaining of the waste of paper at a time when much better use could have been made of it.

While these futilities were being enacted in the Inoculation Department, there were more relevant events in other parts of the world. Florey and the Oxford workers turned their attention to infection of wounds in the Birmingham Accident Hospital and as far afield as the western desert in North Africa, where quite astonishing results were obtained. More by accident than design, St Mary's Hospital also played its part, for during 1942, a patient with the symptoms of meningitis was admitted. After some difficulty, it was found that the infection was due to haemolytic streptococci. The usual treatment with sulphonamides was not proving effective and the prognosis was grave.

It was at this stage, on 5 August, that Fleming asked Florey whether he would be prepared to give him penicillin. Florey was good enough to travel at once to London with all he possessed, and told Fleming how to use it. ${ }^{52}$ It was given at first by intravenous injection every three hours, for six days, and had produced some improvement by 11 August, but not a cure. This would not have surprised Fleming, as he would have assumed that much of it had become inactivated by the blood before it reached the meninges. For this reason, and after consultation with Florey, Fleming did what had never been done before, he avoided transportation by the blood and

\footnotetext{
49 Noble, op. cit., note 10 above, p. 127.

so Cope, op. cit., note 3 above, p. 177.

s1 Ibid.

32 Macfarlane, op. cit., note 45 above, p. 348.
} 


\section{Ronald Hare}

injected the penicillin directly into the cerebrospinal fluid. Improvement started at once, and on 28 August the patient was able to leave his bed. ${ }^{53}$ This, although Fleming never claimed as much, showed that penicillin had been applied locally and proved a success even though the infection had been in one of the most inaccessible parts of the body. He had done what he had wanted to do twelve years previously - avoid transport by the blood and go direct to the lesion.

\section{FLEMING BECOMES A CELEBRITY}

Although Fleming had discovered lysozyme in 1922 and penicillin in 1928, very few medical men and even fewer of the laity had heard of him, but almost overnight this anonymity came to an end. The process began while the meningitis patient was still in hospital, with the publication by The Times on 27 August 1942 of a leading article headed 'Penicillium'. It drew attention to the discovery of a new substance with almost miraculous curative properties, but no names or places were mentioned. How The Times acquired this information is unknown, but the next day, Friday 28 August, Wright wrote the following letter to The Times, which, owing to the intervention of the weekend was not published until Monday 31 August:

In the leading article on penicillin in your issue yesterday you refrained from putting the laurel wreath for this discovery round anybody's brow. I would, with your permission, supplement your article by pointing out that, on the principle palmam qui meruit ferat, it should be decreed to Professor Alexander Fleming of this research laboratory. For he is the discoverer of penicillin and was the author also of the original suggestion that this substance might prove to have important applications in medicine.

The mere fact that Fleming was mentioned was enough to send every available reporter to St Mary's for further information that same day. Among them was Miss Audrey Russell, the well-known broadcaster, and it was her first assignment as a cub reporter for the BBC. She remembers the occasion vividly, and was kind enough to let me have her account of her day's work:

\footnotetext{
Already there were a number of journalists and photographers present clamouring for pictures, statements, etc. Professor Fleming made a brief appearance for pictures and quickly disappeared to some inner sanctum saying he did not want to be interviewed. A handout was distributed which helped us to understand a little of what penicillin really was and what it would do. I decided to stay on in the chance of catching Fleming as he went to lunch.

I did so but he again refused to be interviewed. In the afternoon I contacted a doctor who had been organizing the press in the morning, emphasising the National importance of the interview....

About 6 o'clock Fleming emerged and was most kindly and sympathetic about my wait. He agreed to come with me to the BBC in about an hour's time. He seemed reticent, modest and even nervous about his broadcast before we even got to the studio.
}

His reason for agreeing to help Miss Russell was almost certainly because she sought speech rather than mere words, as sufficed for newspaper reporters. This makes it extremely improbable that Fleming had been responsible for anything that had led to the siege of his Department.

It is also difficult to believe that Wright had, of his own volition, written the letter that brought about the siege, in view of the fact that he was engaged at the time in the expensive business of republishing his own papers to secure his own immortality and not that of Fleming, to whom he behaved very badly on several subsequent occasions. If the "persuasion" of Wright was required to get the letter signed, the only person at

${ }^{33}$ A. Fleming, 'Streptococcal meningitis treated with penicillin', Lancet, 1943, ii: 434-438. 


\title{
Other scientific activities of Alexander Fleming
}

St Mary's who could have done so was Moran. In fact, it is quite possible that Moran wrote the letter and threatened that if Wright refused to sign it, he himself would do so in his capacity as Dean of the Medical School. Not being averse to a little personal publicity, Wright duly signed it, and Fleming's reputation was made.

There is, of course, no proof whatever that this had been the true series of events, but there is certainly evidence that Moran was in London at the material time. According to Lord Alanbrooke's diaries, ${ }^{54}$ Moran fiew with Churchill to Cairo on 31 July (and may even have heard about the meningitis patient before he left). They then went to Moscow for deliberations with Stalin, and returned to Cairo, which they left on the morning of 24 August, eventually arriving at Paddington at 11.45 p.m. Moran would therefore have had sufficient time to organize the leak to The Times for publication on 27 August and the persuasion of Wright for publication of his letter on 31 August.

It is possible that the siege of St Mary's on 31 August was more tempestuous than Moran had anticipated, but it must be recalled that the fortunes of the western allies were then at their lowest ebb, with a long series of defeats or surrenders, the most recent being that of Dieppe on 19 August. The turn of the tide at El Alamein was still fifty-three days away, and certainly Churchill (and Moran) had had to endure a barrage of insults from Stalin in the Kremlin. But here was something that was more humanitarian than high explosive, that Stalin could not match. Who can blame Moran if he saw his opportunity and made the most of it?

During these events, Florey and his team went unnoticed. To remedy this, Sir Robert Robinson, the Professor of Chemistry at Oxford, wrote the following letter to The Times, dated 1 September and published on Wednesday 2 September 1942:

\begin{abstract}
Now that Sir Almroth Wright has rightly drawn attention to the fact that penicillin was discovered by Professor Fleming and has crowned him with a laurel wreath, a bouquet at least and a handsome one, should be presented to Professor H. W. Florey, of the School of Pathology at this university. Toxic substances are produced by the mould alongside penicillin and Florey was the first to separate "therapeutic penicillin" and to demonstrate its value clinically. He and his team of collaborators, assisted by the Medical Research Council, have shown that penicillin is a practical proposition.
\end{abstract}

This naturally led to a stampede of reporters (which did not include Miss Russell) to Oxford, but they got no farther than the front door of the laboratory, and the telephone remained unanswered. If, thereafter, the Oxford team tended to be ignored in the plaudits, it was largely their own fault. In any event, they did not do so badly in the long run, particularly Florey, who achieved a share in a Nobel Prize, the Fellowship and later the Presidency of the Royal Society, the Provostship of Queen's College, Oxford, the Order of Merit, and a life peerage. Chain, too, shared in a Nobel Prize and was elected FRS. He eventually occupied a well-endowed chair in the Imperial College of Science and Technology, London. Financially, he may have done better than the others, in view of the part he played in the development of the semi-synthetic penicillins.

\footnotetext{
s4 Sir Arthur W. M. Bryant, The turn of the tide 1939-43. A study based on the diaries and autobiographical notes of Viscount Alanbrooke, London, Fontana, 1965, pp. 398-399.
} 


\section{Ronald Hare}

Trials and rewards of a celebrity

When Fleming became a celebrity in 1942, he had, up to that time, led a comparatively comfortable scientific life. He was soon faced with the necessity of addressing audiences, some of whom might be critical or even hostile. He was very badly equipped to deal with this situation, being not only a shy and poor speaker but quite incapable of the humour and irony that sometimes rescue those in trouble. What he said on these occasions I have already discussed in this journal. ${ }^{55}$ It had become obvious that his account of the discovery in the original paper was no better than a series of guesses founded for the most part on his assumption that penicillin acted in the same manner as lysozyme. By 1942, he realized that such had not been the case and made several unsuccessful efforts to substantiate his story.

It was about that time that his fame was increased as a result of this telling a journalist that the mould had come from the atmosphere in Praed Street by way of an open window. Since this implied assistance by the Almighty, it became a prominent feature of the penicillin myth. Nevertheless, within three months of the discovery, Fleming had obtained good evidence that it had come from a mycological laboratory on the floor below. In any case, he knew perfectly well that his window had not been opened or (as one account had it) broken.

Why he had allowed penicillin to lie fallow for the best part of twelve years was, however, a more difficult question to answer, because the reasons that had seemed adequate in 1931 could not be quoted as evidence in the 1940s because they had never been properly investigated. To overcome this difficulty, he resorted to a series of complaints: penicillin was so unstable; the clinicians had failed to provide cases suitable for treatment; and his two assistants, Ridley and Craddock, had failed to supply a suitable concentrated and purified solution of the new substance. Although these complaints may appear genuine, a great deal of highly important information was omitted: the instability of penicillin had been largely overcome within six months of its discovery by adjusting the $\mathrm{pH}$ and storing at $0^{\circ} \mathrm{C}$ which gave it a useful life for up to three months: few clinicians would have been at all enthusiastic about treating their patients with broth in which a mould had grown; but perhaps his most unfortunate omission was the fact that Ridley and Craddock had produced in their last experiment $120 \mathrm{ml}$ of a largely or completely alcohol-free solution containing all the penicillin originally in $1,200 \mathrm{ml}$ of broth. ${ }^{36}$ These excuses were put forward in four different countries and published in journals with very limited circulation and unlikely to be read by the St Mary's clinicians or Ridley and Craddock. Thus, Fleming succeeded in disguising the facts that he did not know how he discovered penicillin or why he had been so misled afterwards. He succeeded in surviving, but, like Waterloo, it must have been a close-run thing on more than one occasion.

However, he could console himself that in the course of the years he collected a great many honours. This process began, fittingly, with the award of the Fellowship of the Royal Society in 1943, as a result of the customary election by the existing Fellows. I strongly suspect that it was not his first attempt to join the "invisible college", if only because publication in the Proceedings usually gives some indication

3s Hare, op. cit., note 27 above, pp. 22-24.

s6 Ibid., pp. 6-8. 


\section{Other scientific activities of Alexander Fleming}

of a desire for immortality on the part of the author. Fleming published two papers in 1922 and a third in 1924. Not long afterwards, sheets of paper headed "Royal Society" with typewritten lists that looked like names and addresses were strewn over the desk in the departmental library one morning - suggestive, but not proof.

In 1944, Fleming rose still higher in the scale of preferment when he was awarded a knighthood, conferred for safety reasons in the basement of Buckingham Palace. He was unwise enough to drop in for tea at St Mary's on the way home. Here, according to Howard Hughes, he encountered Wright in a very bad temper, morose and uncommunicative; and when Craxton arrived with documents for signature, he was told to give them to Doctor Fleming. The latter signed his name, got up, and went home.

Shortly afterwards, Fleming set off for America, accompanied by $\mathrm{Mr} \mathrm{K}$. Cameron, to receive an honorary degree at Harvard University. He also went to Oklahoma City, Chicago, the Mayo Clinic at Rochester, Minn., Toronto, Montreal, and Washington, where he was given the Variety Club's humanitarian award and the United States Medal of Merit.

Owing to the war, Fleming had to wait another year before the most coveted of all the honours could be considered, the Nobel Prize for Medicine. But when Germany collapsed in May and Japan in August 1945, it became apparent that an award would be made during the autumn. Rumours from Stockholm indicated that Fleming was not only the favourite but was to be given the whole of the award. But noises from Oxford caused the judges to reconsider. This time it was to be half for Fleming and a quarter each for Florey and Chain. After more noises, they finally settled for one-third each. All this must have taken time, because it was not until 25 October that the telegram arrived with the news, and on 8 December, Fleming, Florey, and Chain duly received their cheques, delivered their addresses, and returned home.

\section{THE LAST TEN YEARS}

In the ordinary course of events, Fleming would have had to retire from his University of London Chair of Bacteriology in 1946, when he was sixty-five years old, but in 1945, because of the turmoil that was likely to follow the peace, the university authorities had asked him to stay on for a year or two to enable them to find a suitable successor.

His chief, Wright, was in a different category. He had been retired from his professorial chair since 1927, but had continued to act as Director of the Inoculation Department because it was independent of the University and its ruling body considered that age was no bar to scientific research. Because of this, and supported by the Chairman of the Council, Lord Iveagh, and its Treasurer, Lord McGowan, both only seventy-four years old, Wright had been allowed to stay in office all through the war and was eighty-four years old when it ended. Strange as it may seem, the geriatric trio showed no signs of resignation at a time when youth, above all things, was required. Wright was, accordingly, still in full command when Fleming returned from America in July 1945.

To make matters worse, Wright probably encouraged by Freeman, had carried out a major operation on the constitution of the Department, which resulted in its being split into five divisions, each under a director with a seat on the ruling council. Even 


\section{Ronald Hare}

though this might improve matters in the future, there was no need for such haste, and it was certainly bad manners on Wright's part. But far worse was Wright's behaviour towards one of the staff whom he had sacked in a fit of temper. The individual concerned had been one of Fleming's most loyal assistants for about twenty years. Badly wounded in the First World War, he found it very difficult to obtain another post. When, therefore, Fleming returned from America, the correct procedure would have been a furious row with Wright. Fleming, being still a professor and therefore unsackable, even by Wright, would have been in a strong position. But, because the Nobel Prize Committee was still considering the next awards, it would have been very unwise to quarrel with so powerful an adversary as Wright. Nevertheless, this was Wright's last fling, for a year later he was finally persuaded to retire. He died only six months later.

And so, at the age of sixty-five when most men are thinking of retiring, Fleming at last became the Director (the post was now called Principal) of the laboratory (which also changed its name - to the Wright-Fleming Institute) in which he had started work thirty-nine years previously (Figure 5). Its future was, however, by no means certain, for many vaccines had become obsolete as a result of the introduction of the sulphonamides and the antibiotics into clinical medicine. Although vaccines were still required for the prevention of some diseases, their preparation required skills and facilities that were not available in Praed Street. A third and very important factor was the danger that enormous damages could be obtained in the law courts if there was any suspicion that a vaccine had been responsible for injury to a patient. For these reasons, the manufacture and sale of vaccines by what have been called cottage industries was no longer possible or even safe.

Fleming had long been aware of these hazards, but there was little he could do to remedy the situation. ${ }^{57} \mathrm{He}$ therefore concentrated on doing researches he really liked, that is, as mentioned above, the invention of new techniques and the utilization of unusual substances. Even when he became a celebrity, he could not resist the temptation to produce something new, so that when replying to my cablegram congratulating him on his knighthood in the summer of 1944, most of his letter, written in the wonderfully clear hand he always possessed, was a recipe for a test I was unlikely to use because I was making large quantities of penicillin for others to test and employ (Figure 7). And, when receiving his Nobel Prize, he presented a mould colony embedded in a transparent jelly in a watch glass to the Rector during the ceremony.

Fleming's publications at that time also demonstrate his interest in techniques, such as those for the estimation of penicillin potency in blood and body fluids. ${ }^{58}$ The gift of

\footnotetext{
${ }^{37}$ Soon after Fleming's death in 1955, draconian measures had to be taken, such as early retirement or transfer to other institutions. The connexion with Parke Davis came to an end in 1960. The pollen extract for the prevention of hay fever was taken over by Beechams and survived for the next seven years. Being no longer financially viable, the Wright-Fleming Institute lost its independence and was taken over by the Medical School in 1968. See A. A. Glynn, 'Wright-Fleming Institute', St Mary's Hosp. Gaz., 1982, 88: 14-16.

ss A. Fleming, 'Micro-methods of estimating penicillin in blood serum and other body fluids', Amer. J. clin. Path., 1945, 15: 1-6; A. Fleming and G. Smith, 'Estimation of penicillin in serum. Use of glucose, phenol red, and serum water', Lancet, 1947, i: 401-402.
} 


\section{Other scientific activities of Alexander Fleming}

a phase contrast microscope inspired another paper; 99 and a year later, there came with Dr A. G. Ogilvie a long paper recommending the old hot oil bath for the sterilization of syringes, which, had anyone taken notice, might by this time have saved the country millions of pounds for the discardable syringes now universally employed. ${ }^{60} \mathrm{In}$ addition to these technical matters, he invaded entirely new territory with a paper on Louis Pasteur, inspired by an exhibition in London. ${ }^{61}$

The entry of moulds into Fleming's scientific life gave the impetus for the exploitation of their tinctorial potentialities, as well as that of some of the microbes, to such an extent that he used them for the production of coloured pictures. A nutrient agar surface was inoculated with various coloured bacteria, and after incubation the picture emerged (Figure 8). Even more remarkable was the production of miniature gardens complete with herbaceous borders and lawns. It seems a pity that none of them was photographed, for they were very remarkable. Useless and even silly though they may have seemed, these technical procedures gave him immense pleasure.

Another hobby was travel, possibly a lifelong ambition as a result of his early years as a City shipping clerk. He had previously had little opportunity to indulge in this pastime, although he had been taken by Dr Young, a medical officer in a petroleum company, to the Middle East by aeroplane, an adventure in itself at the time. He had also been to New York in the summer of 1939 to attend the Microbiological Congress, but had had to come back because of the international crisis.

When, however, he returned to America in the summer of 1945, he found that there was much to be said for overseas travel if one was a celebrity, a conclusion confirmed by a visit to France soon afterwards. Thereafter, there was no stopping him. His trips were, for the most part, the result of invitations from universities or professional bodies. Although shy and reticent in public, he could, in private and suitably lubricated, be very entertaining, particularly if there were pretty women about - even more so, if there was a football match, or if a putting green could be arranged with a flowerbed for bunkers, while a billiards table for snooker would keep him happy for a whole evening.

Since these trips usually included the conferment of an honorary degree, the gown, hood, and above all the headgear were invaluable when he returned home, because they could be worn at the next university reception - and all the better if the headgear was unusual because it made him conspicuous. This annoyed many members of the bacteriological establishment who might be present, who to a man had thought little of his work. It was his private way of getting his own back.

Nevertheless, although distinguished members of the establishment had reached their eminence as a result of papers in impeccable English describing in minute detail the more trivial events in the world of bacteria, none of them had paid for their researches by taking over the management of a commercial undertaking founded in 1908 with a capital of $£ 17,000$ and which, in the early 1950s, possessed securities

59 A. Fleming, 'Further observations on the motility of Proteus vulgaris on penicillin agar', J. gen. Microbiol., 1950, 4: 437.

${ }^{\circ}$ A. Fleming and A. C. Ogilvie, 'Syringe needles and mass inoculation technique', Br. med. J., 1951, i: 543-546.

${ }^{6}$ A. Fleming, 'Louis Pasteur', ibid., 1947, i: 517-522. 


\title{
Ronald Hare
}

valued at $£ 250,000$, and in the interval had raised $£ 105,000$ for the construction of a five-storey building. Thus, although Fleming ranked as a professor from the end of September 1928, and did, in fact, organize the teaching of bacteriology at St Mary's, he certainly bore no resemblance to the absentminded savant of fiction or to the dedicated seeker of chemotherapeutic substances as portrayed by Maurois and other commentators. He was a hard-headed business man, who not only did all the thinking but most of the work.

If these achievements were not enough, he had, in his spare time, made two major discoveries, one of which has not only relieved human suffering to an unbelievable extent but is now prolonging life to such lengths that over-population of the globe is now facing the human race. With such a history it appears irrelevant to append the usual summary and more relevant to replace it with a quotation from a work by Lord Moran, who knew him better than any of us:

\begin{abstract}
Alexander Fleming had lived in obscurity and in some disfavour. His research into the acne bacillus and the Wasserman [sic] reaction had been generally discredited. He seemed to his profession to be disgruntled by criticism and by neglect; a sour, rather silent Scot. And then, on the verge of old age, he discovered penicillin. He, too, had found a place in the sun, so that it was no longer necessary to stake a claim aggressively. For he knew now that his name had a place in history. Fleming seemed to spend the rest of his days travelling over the world, making modest little speeches implying that there had been a great element of luck in his discovery. Famous universities were proud to give him an honorary degree, and everywhere he went he won men's hearts by his happy simplicity. ${ }^{62}$
\end{abstract}

\section{ACKNOWLEDGEMENTS}

The author wishes to thank Dr W. F. Bynum for his co-operation in the publication of this paper; Mrs Jean Runciman for her care with the quotations and references; Mr N. G. Heatley for reading the manuscript and making useful suggestions; Mr Dorian Robinson for his assistance with the text; and $\operatorname{Dr} \mathrm{N}$. P. Cardew and Professor Ian Phillips for their help with the illustrations.

${ }^{62}$ Charles McMoran Wilson, 1st baron Moran, Winston Churchill: the struggle for survival 1940-65. London, Constable, 1966, p. 489. 